\title{
DISCOVERY FROM THE UNITED STATES IN SUITS BETWEEN PRIVATE LITIGANTS-THE 1958 AMENDMENT OF THE FEDERAL HOUSEKEEPING STATUTE
}

LiTIGants in suits to which the United States is not a party may seek aid from the 1958 amendment ${ }^{2}$ of the federal "housekeeping" statute 2 in their attempts to obtain government-held information which, while not privileged," may not be divulged by subordinate officials under department regulations. Such information is often contained in records in the custody of subordinates filed in local offices ; ${ }^{4}$ and, under the Federal Rules of Civil Procedure, litigants can cause subpoenas ordering disclosure to be served upon these local officials." Executive department heads residing and working in Washington, however, will ordinarily not be amenable to process of the court where the action is pending. ${ }^{6}$ And, although a litigant could initiate collateral proceedings in the District of Columbia to reach the appropriate department head, ${ }^{7}$ these proceedings would not only be inconvenient, costly, and time consuming, but quite possibly fruitless, since it has never been held that a department head can be compelled to respond to such a subpoena. ${ }^{8}$ Therefore, unless courts enforce

1. 72 Stat. 547 (1958), 5 U.S.C. $\$ 22$ (1958). For the text of the amendment, sec text at note 23 infra.

2. Rev. Stat. § 161 (1875), as amended, 5 U.S.C. $\S 22$ (1958). For the text of the unamended statute, see text at note 10 infra.

3. This Note will restrict the term "privilege" to rights to withhold information the disclosure of which the common law or specific statutes deem contrary to the public interest. "Governmental privilege" thus encompasses such information as military secrets, e.g., United States v. Reynolds, 345 U.S. 1, 6-7 (1953); 35 U.S.C. \$§ 181-88 (1952), diplomatic secrets, e.g., Republic of China v. National Union Fire Ins. Co., 142 F. Supp. 551 (D. Md. 1956), and the identity of informers, e.g., Roviaro v. United States, 353 U.S. 53, 59-61 (1957) ; Henrik Mannerfrid, Inc. v. Teegarden, 23 F.R.D. 173, 175-76 (S.D.N.Y. 1959). See generally 8 Wigrore, Evidence $\S \S 2374,2378$ (3d ed. 1940). Nondisclosure based on regulations promulgated under the housekeeping statute has, however, been referred to as a "privilege" elsewhere. E.g., McCoRMick, Evidence § 145 (1954); Note, 68 YALE L.J. 1409, 1419 n.47 (1959).

4. Timbers \& Cohen, Demands of Litigants for Government Information, 18 U. PITr. L. Rev. 687, 689 (1957); see, e.g., United States ex rel. Touhy v. Ragen, 340 U.S. 462 (1951) (FBI reports); Boske v. Comingore, 177 U.S. 459 (1900) (tax reports); $c$. Appeal of the United States Sec. \& Exch. Comm'n, 226 F.2d 501 (6th Cir. 1955) (SEC records desired in conjunction with stockholders' derivative suit).

5. See FED. R. CIV. P. 26(a), 45(d) (1).

6. See Fed. R. Civ. P. 45(d) (1), 45 (e) (1); 5 Moore, Federal Practice fif 45.07, 45.09 (2d ed. 1951) [hereinafter cited as MoORE].

7. For the proper method of initiating collateral proceedings, see 5 Moons $\Uparrow 45.07$.

8. Bishop, The Executive's Right of Privacy: An Unresolved Constitutional Qucstion, 66 Y ALE L.J. 477, 478 \& n.5 (1957). It has been asserted that the President and department heads are inherently immune from subpoenas-an immunity based upon the Constitution. See White House Press Release, Aug. 12, 1958 (statement of President Eisenhower). set out in Hennings, Constitutional Law: The People's Right To Know, 45 A.B.A.J. 
subpoenas issued against subordinates, litigants who need governmental information will often be left dependent upon voluntary disclosure by a department head. ${ }^{9}$

But permissive legislation, executive regulations, and judicial interpretation have combined to render these subpoenas unenforceable. Title 5 , section 22 of the United States Code-the "housekeeping" statute-provides:

The head of each department is authorized to prescribe regulations, not inconsistent with law, for the government of his department, the conduct of its officers and clerks, the distribution and performance of its business, and the custody, use, and preservation of the records, papers, and property appertaining to it. ${ }^{10}$

Pursuant to this statute, heads of executive departments have regularly promulgated regulations withdrawing from subordinates all discretion to divulge official information. ${ }^{11}$ When a subordinate is ordered by subpoena to allow discovery, these regulations require him to pass the court order, together with his recommendation as to compliance, through the administrative hierarchy up to the department head. ${ }^{12}$ If the latter decides to release the information, the sub-

667 (1959); 20 Ors. Att'y Gen. 557 (1893); 25 Ops. Att'y Ger. 326 (1905); 40 Ops. ATT'Y GEN. 45 (1941) ; Brownell, Mlemorandun oit Separation of Powers, 14 FED. B.J. 73, 74 (1954); Rogers, Constitutional Law: The Papers of the Execulise Branch, 44 A.B.A.J. 94 (1958); Wolkinson, Demand of Congressional Commiltees for Excculize Papers, 10 FED. B.J. 103, 223, 319 (1949) ; 36 B.U.L. REv. 118, 121-22 (1956). Other commentators have expressed the view that courts could not or should not force department heads to release information. See 4 Mroore II 26.25[5] ; Haydock, Some Ezidculiary Problems Posed by Atomic Energy Security Requirements, 61 HARv. L. Rev. 468, 472-78 (1948) ; Timbers \& Cohen, supra note 4, at 714-15; Note, 47 Nw. U.L. RE: 519, 528-29 (1952). Most commentators, however, have opposed executive immunity from judicial or congressional demands for information. See, e.g., 8 Wrasrore, Evidence $\$ 2378$ (a) (3d ed. 1940); Berger \& Krash, Govermment Immanity From Discoucry, 59 Yale L.J. 1451, $1462-64$ (1950) ; McAllister, Executive or Judicial Determination of Privilege of Government Documents?, 41 J. CRns. L. \& Crnarnology 330, 332, 334-35 (1950); Saniord, Evidentiary Privileges Against the Production of Data Within the Control of Exceutive Depariments, 3 Vand. L. Rev. 73, 94-96 (1949) ; Comment, 18 U. Cri. L. Rev. 122, 127-28 (1950); 35 MIINN. L. REv. 586, 589 (1951).

In a celebrated early case, Mír. Chief Justice Mrarshall asserted that President Jefierson was subject to subpoena ad testificandum concerning certain letters. United States v. Burr, 25 Fed. Cas. 187, 190-92 (No. 14694) (C.C.D. Va. 1807). But see United States v. Cooper, 25 Fed. Cas. 631, 633 (No. 14865) (C.C.D. Pa. 1800) (refusal to issue subpoena against President Adams). Marshall's assertion in Burr was mooted, however, since President Jefferson eventually furnished the letters voluntarily. See Berger \& Krash, sipra at 145060.

9. Voluntary disclosure will be forthcoming in many instances. Timbers \& Cohen, supra note 4, at 708-09.

10. Rev. Stat. § 161 (1875), as amended, 5 U.S.C. § 22 (1958). (Emphasis added.)

11. Cross, The People's Right To Know 214-15, 230, $237-42$ (1953); Mlitchell, Go:ermnent Secrecy in Theory and Practice: "Rules and Regulations" as an Antonomons Screen, 58 Coluar. L. Rev. 199, 204 (1958).

12. E.g., Order of the Attorney General, 18 Fed. Reg. 1368 (1953). 
poena will be obeyed. If he decides to withhold the information, the subordinate will appear in court and "respectfully decline to produce the records or information"13 on the ground that disclosure is prohibited by regulation." Although refusal to respond to a reasonable subpoena is ordinarily grounds for a contempt proceeding, ${ }^{15}$ the Supreme Court has interpreted section 22 and regulations promulgated thereunder to immunize from punitive judicial sanctions subordinate officials subpoenaed in actions between private litigants. Boske v. Comingore ${ }^{16}$ and United States ex rel. Touhy v. Ragen ${ }^{17}$ held that section 22 was constitutional ${ }^{18}$ and that nondisclosure regulations were within the contemplation of the statute. ${ }^{10}$ Boske and Touhy further held that, since the subordinates were prevented by valid regulations from obeying court disclosure orders, they could not be held in contempt. ${ }^{20}$ Neither Boske nor Toulhy decided that section 22 confers a statutory privilege or executive immunity upon department heads to withhold information in an action between private litigants. They decided only that the courts had supoenaed the wrong man.21 Despite

13. Ibid.

14. See United States ex rel. Touhy v. Ragen, 340 U.S. 462 (1951); Boske v. Comingore, 177 U.S. 459 (1900) ; Jackson v. Allen Industries, Inc., 250 F.2d 629 (6th Cir.), cert. denied, 356 U.S. 972 (1958); Ex parte Sackett, 74 F.2d 922 (9th Cir. 1935) ; cf. Appeal of the United States Sec. \& Exch. Comm'n, 226 F.2d 501 (6th Cir. 1955).

15. See 18 U.S.C. $\S 401$ (1958) ; FED. R. Crv. P. 37 (b) (1), 45(f); Penficld Co. v. SEC, 330 U.S. 585 (1947).

When the Government is a party, courts may employ methods of enforcing discovery orders. When the Government is plaintiff, the action can be dismissed. Mitchell v. Bass, 252 F.2d 513 (8th Cir. 1958); United States v. Cotton Valley Operators Comm., 9 F.R.D. 719 (W.D. La. 1949), aff'd per curiam by an equally divided Court, 339 U.S. 940 (1950). When the Government is defendant, the introduction of government evidence on certain points can be prohibited, Bank Line, Ltd. v. United States, 76 F. Supp. 801, 805 (S.D.N.Y. 1948) ; O'Neill v. United States, 79 F. Supp. 827 (E.D. Pa. 1948), rev'd on other grotmds sub nom. Alltmont v. United States, 177 F.2d 971 (3d Cir. 1949), ccrt. denied, 339 U.S. 967 (1950), or the facts can be taken as established against the Government, Reynolds v. United States, 192 F.2d 987 (3d Cir. 1951), rev'd on a finding of govermmcm privilege, 345 U.S. 1, 10 (1953), or any orders can be made in regard to the disposition of the case which are just, FED. R. CIv. P. 37(b). But see Fed. R. Civ. P. 37 (f) (denying the courts power to assess costs against the Government for unreasonable failure to comply with discovery rules); 55 (e) (preventing default judgments against the Govcrnment). In criminal prosecutions, courts have held that the Government can claim privilege only at the price of dismissal of the indictment. See, e.g., United States v. Andolschek, 142 F.2d 503, 506 (2d Cir. 1944); United States v. Beekman, 155 F.2d 580, 584 (2d Cir. 1946). See generally 4 MOORE \I $26.25[6]$.

16. 177 U.S. 459 (1900).

17. 340 U.S. 462 (1951).

18. 177 U.S. at $468,469$.

19. Id. at $470 ; 340$ U.S. at 468 .

20. 177 U.S. at 467,$470 ; 340$ U.S. at 469 . But cf. United States v. Hall, 153 F. Supp. 661, 666-67 (W.D. Ky. 1957) (criminal case recognizing Touhy, but nonetheless finding subordinate in contempt, fining him $\$ 1,000$, suspending imposition of that sentence, and continuing case).

21. We find it unnecessary, however, to consider the ultimate rach of the authority of the Attorney General to refuse to produce at a court's order the government 
this narrow holding, however, the practical effect of these cases would not have been greater had they expressly ruled that department heads need not respond to a subpoena. ${ }^{22}$ Since subordinate officials within a court's jurisdiction cannot under Boske and Touhy be held in contempt, and since the trial court ordinarily has no jurisdiction over the department head, discretion as to what information, if any, will be released lies with the department's chief. Thus, even though Congress has not specifically authorized nondisclosure and the courts have not yet sanctioned executive immunity from subpoenas, any information which a department head does not want released for any reason-evidentiary privilege, administrative inconvenience, even reluctance to publicize departmental mistakes -is unavailable to litigants.

In 1958, section 22 was amended to provide: "This section does not authorize withholding information from the public or limiting the availability of records to the public."23 Whether regulations under section 22 will still constitute a defense to contempt is an unsettled question. No apposite cases have been reported since passage of the amendment and commentators disagree on its effect. One, for example, advocates a new amendment "authorizing the issuance of regulations governing discolsure of information by subordinate agency officials ... [to] preserve the rules of the Boske and Toulty cases." "-14 Since this writer suggests congressional action to resucitate Boskc and Touhy, he must believe, at least, that the amendment precludes the use of section 22 regulations as a defense to contempt. ${ }^{25}$ On the other hand, the counsel of

papers in his possession, for the case as we understand it raises no question as to the power of the Attorney General himself to make such a refusal. . . The a alidity of the superior's action is in issuc only insofar as we must determine whether the Attorney General can validly withdraw from his subordinates the poiter to relcase department papers.

340 U.S. at 467 . (Emphasis added.) See id. at 471 (concurring opinion of Frankfurter, J.). But see United States v. Andolschek, 142 F.2d 503, 506 (2d Cir. 1944) (dictum) (L. Hand, J.) ; cf. Appeal of the United States Sec. \& Exch. Comm'n, 226 F.2d 501, 517, 520 (6th Cir. 1955); Universal Airline, Inc. v. Eastern Air Lines, Inc., 18S F.2d 993, 1000 (D.C. Cir. 1951).

For discussions of the limits of the Boske and Toulyy holdings, see Bishop, supra note 8 , at 478-79; Mitchell, stpra note 11, at 205; Schwartz, Executive Privilege and Conyressional Investigatory Power, 47 CaLIF. L. Rev. 3, 13-14, 18 (1959).

22. Of course, an actual holding of executive immunity would sender nugatory collateral proceedings instituted in Washington for the purpose of obtaining jurisdiction over a department head. But collateral proceedings have apparently not been used by litigants. See note 8 supra and accompanying text.

23. 72 Stat. 547 (1958), 5 U.S.C. $\$ 22$ (1958).

24. Carrow, Government Nondisclosure in Judicial Proceedings, 107 U. PA. L. Ra. 166 (1958).

25. Mr. Carrow also seems to say that, apart from the question of response to a subpoena, department heads can no longer issue regulations under 22 dealing with nondisclosure by subordinates. Ibid. A similar interpretation of Congress' intent appears in Timbers \& Cohen, sipra note 4, at 691 n.S. For another view that Boske is no longer good law, see Donaldson, New Law May End Prizilege on IRS Records, Agent's Testimony, in Civil Tax Litigation, $10 \mathrm{~J}$. Taxation 38, 39 (1959). 
the House subcommittee responsible for the amendment stated, in an article published before enactment, that the amendment simply clarifies existing case law by emphasizing that section 22 confers no authority upon the head of a department to suppress information. ${ }^{26}$ Under his view, department heads can still centralize discretion to deal with discovery requests and thus immunize subordinates from contempt.

Faced with an uncooperative subpoenaed subordinate official, a court could interpret the amendment to permit holding him in contempt. Arguing from the premise that the amendment's purpose is prohibition of the use of 22 to withhold or limit the availability of information in any way, a court might rule that regulations promulgated under 22 which centralize discretion to disclose in the department head would limit the availability of information and therefore be unauthorized. Such a ruling would strip Boske and Touly of their force; section 22 nondisclosure regulations would no longer shield subordinates from contempt proceedings. Invalidating nondisclosure regulations would not actually overrule Boske and Touhy, however. These cases could be interpreted to hold that only validly issued regulations are absolute defenses to contempt. Since section 22 has been amended, regulations which would withhold information are no longer valid, and therefore unavailable as a defense. A portion of the congressional debates conceivably supports this view. ${ }^{27}$

Nevertheless, a court determining congressional intent would find that the weight of legislative history indicates that Congress did not wish to restrict Boske and Touhy, ${ }^{28}$ but meant only to halt 22 's invocation as the basis for refusals by department heads to divulge information. The bill's proponents were concerned with a department's ultimate power to withhold information, and not with a department head's power over his staff or resistance to subpoenas by subordinate officials. ${ }^{20}$ Congress felt that 22 was being miscited as statutory authority for nondisclosure, ${ }^{30}$ and that department heads refusing to disclose

26. Mitchell, supra note 11, at 207-08; see Schwartz, supra note 21, at 18-19.

27. See 104 Cong. Rec. 15695 (1958) (remarks of Senator Johnston).

28. "Those decisions [Boske and Touhy] which, in my opinion, correctly interpret titlc 5, United States Code, section 22, would not be affected at all by the amendment. They would remain the law of the land." Id. at 15695 (remarks of Senator Johnston, quoting Dr. Harold L. Cross). (Emphasis added.)

29. For example, in response to a charge that the amendment might be interpreted to deny department heads power to regulate the manner in which subordinates handled requests for information, the subcommittee's chief counsel stated categorically that the amendment would not "overrule or change in any way the two major decisions of Boskc and Touhy." Hearings on Availability of Information From Federal Departments and Agencies Before a Subcommittee of the House Committee on Govermment Operations, 84th Cong., 1st Sess., pt. 11, at 2558-59 (1957).

30. Now, why do we seek to amend this particular section of the law? ... The answer is very simple. The Special Public Information Subcommittee . . . in conducting a study on the whole problem of Government information ... submitted a questionnaire to all agencies of the Government .... .

One of the questions in this ... questionnaire ... was "By what authority do 
should be forced to rely specifically on privilege or immunity. ${ }^{31}$ Thus, since Congress enacted the amendment simply as insurance-w"wholly consistent with the Supreme Court decisions on the subject"32 - against employment of 22 to clothe a department head with ultimate authority to vithhold information, a court would probably conclude that his right to centralize discretion in himself was untouched and that regulations under 22 continue to immunize subordinate officials from contempt.

It is not the purpose of [the amendment] ... to affect the decision in Touhy $v$. Ragen. Insofar as [the amendment] . . . is concerned, the holding in that case would remain the law of the land, since [the amendment] ... goes only to the authority of the department head himself, and seeks to make it clear that section [22] ... does not authorize executive department heads to withhold information. ... $3^{33}$

Moreover, the amendment fails to effect any practical changes. 34 Since the trial court will ordinarily not have jurisdiction over the department head,

you claim or do you exercise the right to withhold information?" . . . And, we find section 22 , title $5, \ldots$ was cited as legal authority by the [Departments] . . of Agriculture, ... Commerce, ... Defense [etc.] ... .

104 CoNg. REc. 6559 (1958) (remarks of Representative Fascell).

The reason the language is added that it is not authority for withholding is that in 3 years of careful study we have found far too many instances where exeeutive departments have relied upon this statute as a clear authority to refuse information to the public or to the Congress itself.

Id. at 6572 (remarks of Representative MIoss).

31. If they want to claim a privilege, let them claim it, either under the Executive privilege or under the specific statute of Congress, but let us not permit them to use a statute which does not have this intent and never had that intent.

Id. at 6560 (remarks of Representative Fascell). The amendment proponents did not concede, however, that executive immunity exists. Id. at 6572 (exchange between Representatives Moss and Johansen).

32. See H.R. Rep. No. 1461, 85th Cong., $2 d$ Sess. 7 (1958). For the amendment to have been wholly consistent with Boske and Touly, it must be directed to the question not decided by those cases-the ultimate authority of a department head to withhold information under 22.

33. 104 CoNg. REC. 15689 (1958) (letter from Senator Hennings, Chairman of the Senate Committee, to Senator Russel). "To whatever extent section [22] . . now: authorizes ... the head of any of the ... executive departments to preseribe regulations instructing his employees to refer requests for certain information to him for decision, such authority will remain unchanged by the proposed amendment." Id. at 15695 (remarks of Senator Johnston).

34. Although the amendment will prevent the Executive from citing 22, as authority for nondisclosure to Congress, see note 30 sipra, it will not meaningfully alter the relationship between the Executive and Congress. Underlying any citation of 22 is the Exccutive's claim of "inherent" executive immunity. See note 8 supra. This fact is pointed up by the novelty that would be presented if executive withholding of information from Congress were ultimately based on a statute; "what Congress hath given, Congress can talic away." Bishop, supra note 8, at 478-80. In addition, the amendment does not convert the statute into a positive declaration of the right of individuals or newspapers to information. In 
what authority he relies on to withhold information will continue to be insulated from adjudication; as a practical matter, the amendment will not force him to rely on privilege or immunity. ${ }^{35}$

Insulation of official information from compulsory process, left intact by the 1958 legislation, is particularly unsatisfactory since executive departments are unlikely to exercise voluntary disclosure in a manner conducive to thorough discovery. Information should be readily discoverable unless imperatives exist which outweigh the benefits deriving from trials conducted in the light of all relevant facts. ${ }^{36}$ Such a balancing of competing interests ${ }^{37}$ requires impartial analysis and is inherently a judicial function. ${ }^{38}$ When a request for information reaches

the absence of such a statute, it is extremely doubtful that the courts will enforce such all alleged right-despite its purported origin in the Constitution or Declaration of Independence. See United States ex rel. Stowell v. Deming, 19 F.2d 697 (D.C. Cir.), cort. denied, 275 U.S. 531 (1927); Parks, The Open Government Principle: Applying thi Right To Know Under the Constitution, 26 GEo. WASH. L. REv. 1, 13-22 (1957). Nor will the amendment substantially affect suits to which the Government is a party, since when the Government brings suit or allows itself to be sued, it waives any right of nondisclosure based on the housekeeping statute. See, e.g., Fleming v. Bernardi, 1 F.R.D. 624 (N.D. Ohio 1941) (Government plaintiff) ; Cresmer v. United States, 9 F.R.D. 203 (E.D.N.Y. 1949) (Government defendant). But departments have continued to invoke \$ 22. The amendment might therefore have the effect of causing them, when engaged in litigation and desiring to withhold information, to cease relying on this statute. Sce Mitchell v. Roma, 22 F.R.D. 217 (E.D. Pa. 1958), rev'd, 265 F.2d 633 (3d Cir. 1959), in which section 22, relied upon below by the Secretary of Labor before the passage of the amendment, was abandoned on appeal, subsequent to the enactment of the amendment, at authority for nondisclosure.

The amendment, characterized by the chairman of the House Subcommittee on Government Information as a "timid first step," 104 Conc. REC. 6550 (1958), does have the virtue of signifying an aroused attitude on the part of Congress in regard to exccutive disclosure. In addition, the subcommittee has been instrumental in the passage of other statutes which are "steps" (if not giant ones) in the right direction. Sce INT. REv. Cont of 1954, § 6104 (requirement that information which serves as a basis for granting tax exempt status be made public); National Aeronautics and Space Act of 1958, $\$ 303,72$ Stat. 433, 42 U.S.C.A. $\S 2454$ (Supp. 1958) (with certain exceptions, the new National Aeronautics and Space Administration Agency must make public information "obtained or developed by the Administrator in the performance of his functions. . . "). For a detailed discussion of the subcommittee's purpose and accomplishments, sec STAFF of House Subcomm. on Government Information 85th Cong., 2p Sess., Freedom op Information Legislation During the 85th Congress (Comm. Print 1958).

35. Thus, at least in the context of discovery against the Government by litigatuts in private law suits, Congress's intent will be defeated. See 104 CoNG. REc. 6564 (1958) (Representative Moss: "I hope that it will require the departments of Government merely to cite appropriate legal authority for the withholdings.").

36. See McMann v. SEC, 87 F.2d 377, 378 (2d Cir.), cert. denied, 301 U.S. 684 (1937) : 8 WIGMORE, EVIDENCE $\S \S 2192,2197,2285$ (3d ed. 1940); MCCORMICK, EVIDENCE $\$ 72$, at 152 (1954).

37. Cf. Roviaro v. United States, 353 U.S. 53 (1957) (informer privilege).

38. 8 WigMore, Evidence $\$ 2379$ (3d ed. 1940); see United States v. Reynolds, 345 U.S. 1, 8 (1953); Mitchell v. Bass, 252 F.2d 513 (8th Cir. 1958); United States v. Certain Parcels of Land, 15 F.R.D. 224, 231 (S.D. Cal. 1953); United States v. Cotton 
a department head he may well be advised to refuse it, ${ }^{30}$ and will not have the time or inclination to make a thorough personal study of the case. These factors, combined with the knowledge that his decision will normally not be reviewed, may result in denial. Litigants, therefore, may be barred access to information which under no rules of evidence could be termed privileged; administative inconvenience is not a compelling reason to keep courts and parties from information which may be essential to the just and enlightened determination of a case. ${ }^{40}$ The emphasis of the Federal Rules of Civil Procedure on broad discovery is based on a policy which makes the inconvenience suffered by litigants and nonlitigants subpoenaed for information a minor consideration. 11 This policy loses no force when the required data is in the possession of an executive department; it could be effectuated in this context only through new legislation.

A reamendment of section 22 should provide specifically that the housekeeping statute's grant of rulemaking power may be used by department heads to centralize in themselves authority to decide whether a subordinate will

Valley Operators Comm., 9 F.R.D. 719 (W.D. La. 1949), aff'd per curiam by an cqually divided Court, 339 U.S. 940 (1950); Zimmerman v. Poindexter, 74 F. Supp. 933, 935 (D. Hawaii 1947), Note, 58 YALE L.J. 993 (1949) ; Evans v. United States, 10 F.R.D. 255, 257 (W.D. La. 1950). But see Walling v. Comet Carriers, Inc., 3 F.R.D. 442 (S.D.N.Y. 1944).

39. See Hearings on Availability of Information from Federal Depariments and Agencies Before a Subcommittee of the House Committee on Goocrnment Operations, 84th Cong., 1st Sess., pt. 1, at 26 (1955) (statement of James Reston) ; H.R. REr. 1461, 85 Cong., 2d Sess. 28, 29 (1958) ; 104 CoNG. Rec. 6551 (1958) (remarks of Representative Hoffman) ; 8 WigMORE, EVIDENCE $\$ 2378$ a, at 792-93 (3d ed. 1940); AfcAllister, Excculiz'c or Judicial Determination of Privilege of Government Documents, $41 \mathrm{~J}$. Carss. L. \& CrasuNology 330, 334 (1950). But see Timbers \& Cohen, supra note 4, at 70S-09.

40. Berger \& Krash, supra note 8, at 1465-66; 35 MINN. L. REv. 586, 589 (1951); cf. Ex parte Uppercu, 239 U.S. 435 (1915).

41. Rule 45(d) (1) provides for the issuance of subpoenas commanding the production of "books, papers, documents, or tangible things which constitute or contain evidence relating to any matters within the scope of the examination permitted by Rule 26(b)." The only limitations on the scope of such examinations in rule $26(\mathrm{~b})$ are relevance and privilege. The term privilege, as used therein, has the same meaning as that adopted in this Note. See note 3 supra; United States v. Reynolds, 345 U.S. 1, 6 (195j); 4 MOORE II 26.22. Inconvenience would not, therefore, constitute "privilege." But under rule 30 (b) the court can "make any ... order which justice requires to protect the ... witness from annoyance, embarrassment, or oppression." And rule 45(b) specifies that the court can quash or modify the subpoena if it is unreasonable and oppressive or can condition its issuance upon the advancement by the moving party of the reasonable costs of producing the requested records.

For discussion of the purpose of the discovery rules see Hickman v. Taylor, 329 L.S. 495 (1947); 4 Moone II 26.02; Pike \& Willis, The New Federal Deposition Disecictry Procedure (pts. 1 \& 2), 38 CoLux. L. Rev. 1179, 1190, 1191, 1436, 1411 (1938); Pike \& Willis, Federal Discovery in Operation, 7 U. CHI. L. Rev. 297, 301-07 (1938); Sunderland, Discovery Before Trial Under the New Federal Rules, 15 TENN. L. REv. 737 (1939). See generally Speck, The Use of Discovery in United States District Courts, 60 Y ALE L.J. 1132; 1155 (1951). 
comply with a subpoena or resist on grounds of privilege, immunity, undue burdensomeness, or lack of necessity to the litigant's case. But once such clainss are made and adjudged by the court, ${ }^{42}$ the new legislation should prevent a department head from using regulations under 22 to prevent compliance with a subsequent court order to disclose. ${ }^{43}$ Permitting the courts to decide whether particular information in the possession of executive departments should be insulated from discovery need not result in indiscriminate governmental dis. closure or unnecessary administrative inconvenience. To avoid irresponsible and burdensome inquiries, the court should initially require a litigant to demonstrate that desired information is unavailable from other sources and essential to the adequate presentation of his case. ${ }^{44}$ In short, the recommended reamend-

42. If a formal claim of evidentiary privilege is made, the court, following the procedure of United States v. Reynolds, 345 U.S. 1 (1953), would ascertain whether circumstances are appropriate for invocation of privilege, $i d$. at 8-11. If the basis of the asserted privilege is of sufficient national concern, the court could uphold the Government's claim without examination. Ibid. If the claim is based on anything else, the court would view the information in cantera, see e.g., United States v. Ebeling, $146 \mathrm{~F} .2 \mathrm{~d} 254$ (2d Cir. 1944), and make appropriate rulings for the protection of any existing privilegc, such as upholding the right to nondisclosure, see United States v. Reynolds, supra, ordering partial disclosure, see United States v. Certain Parcels of Land, 15 F.R.D. 224, 236 (S.D. Cal. 1953), or requiring disclosure to the persons immediately affected, United States v. Burr, 25 Fed. Cas. 187, 192 (No. 14694) (C.C.D. Va. 1807). If the information is not privileged, contempt proceedings could be held against the subordinate. Due to the unusual nature of the contempt, sanctions should be limited to fine, which would presumably be paid by the department, not the individual, rather than imprisonment. Prestumably, however, the fine would be avoided by compliance with the court's order. For discussions of the purpose and nature of civil contempt, see Gompers v. Buck Stove \& Range Co., 221 U.S. 418 (1911) ; In re Nevitt, 117 Fed. 448, 461 (D.C. Cir. 1902).

43. In the alternative, Congress could provide for nation-wide service of subpocmas duces tecum against department heads, thus allowing the local courts to obtain jurisdiction over the official who is actually making the decision.

44. This would entail some change in the procedure now in effect under the federal rules pertaining to the issuance of subpoenas. Rules $45(\mathrm{a})$, (d) provide that subpoenas will be issued by the clerk of the court at the request of a party as a matter of coursc. The person served with the subpoena may then move to quash it under the provisions of tule 45(b). Under this procedure, the Government would be forced to go to the expense of opposing all subpoenas before the moving party showed the relevance of the requested information or the difficulty he would encounter in attempting to obtain it elsewhere. Because the Government is in possession of vast stores of information, such a procedure would lead to unnecessary expense and interference with its functions. Sce Pike \& Fisher, Discovery Against Federal Adninistrative Agcncies, 56 HARv. L. Rev. 1125, 1130 (1943). Discovery procedure is flexible and should vary with the equities of each case. See United States v. Kohler Co., 9 F.R.D. 289, 291 (E.D. Pa. 1949). If a subpoena is requested by a party to be issued against the Government, therefore, the provisions of rule 34 should apply-the procedure followed when a litigant attempts to use rule 45 to obtain documents from an opposing party. Rules 34 and 45 are then considered to be in pari materia. North v. Lehigh Valley Transit Co., 10 F.R.D. 38 (E.D. Pa. 1950); 5 MookE II 45.05 [2]. Rule 34 provides that a subpoena directed to an opposing party will only be issued, by order of the court, after a showing of good cause. See Panamusica Vencztucla C.A. v. American Steel Export Co., 16 F.R.D. 280 (S.D.N.Y. 1954); Dellamco v. Grent 
ment would prevent section 22 from functioning as a source of privilege while retaining it as authority for intradepartmental administration. It vould ordinarily compel nondisclosure to be grounded on either executive immunity or evidentiary privilege and, in their absence, afford litigants in suits to which the Government is not a party an opportunity to obtain needed information.

Lakes S.S. Co., 9 F.R.D. 77 (N.D. Ohio 1949); G \& P Amusement Co. v. Regent Theatre Co., 9 F.R.D. 721 (N.D. Ohio 1949) (the information requested should be unavailable from other sources). For the requirement of relevancy, see, e.g., Overby $v$. United States Fid. \& Guar. Co., 224 F.2d 158 (5th Cir. 1955) (court's order for government records held to be too broad, included irrelevant material); State Theatre Co. $v$. Tri-States Theatre Corp., 11 F.R.D. 381 (D. Neb. 1951); Connecticut MLut. Life Ins. Co. v. Shields, 17 F.R.D. 273 (S.D.N.Y. 1955). For a detailed discussion of what constitutes good cause see 4 MOORE IIT 34.08-09.

If the subpoena issues, it must designate the records desired with reasonable particularity. Brown v. United States, 276 U.S. 134, 143 (1928); Consolidated Rendering Co. v. Vermont, 207 U.S. 541, 553-54 (1908). See generally Newport, "Designation" os Used in Rule 34 of the Federal Rules of Civil Procedure on Discovery and Production of Documents, 35 Iowa L. Rev. 422 (1950). 